\title{
Extrahepatic Manifestations of Hepatitis C Virus: An Extending List
}

\author{
Amira M Soliman ${ }^{1}$, Soha A El hawari ${ }^{1}$, Mohamed M Refaey ${ }^{1}$, \\ Nabila H Ahmed ${ }^{1}$, Mohamed H Emara ${ }^{1}$ \\ ${ }^{I}$ Tropical Medicine Department, Faculty of Medicine, Zagazig University, Egypt
}

Corresponding Author Nabila H Ahmed

email:

nabila.hassan25@yahoo.c com

Received : $1 / 1 / 2012$

Accepted after

revision: $5 / 2 / 2012$

Keywords :

HepatitisC, Mixed cryoglobulinemia, Lymphoproliferative disorders, Porphyria cutanea tarda
Hepatitis C virus is a hepatolymphotropic virus that was also detected in various organs of the body. Furthermore, this form of infection may be presented for the first time by an extrahepatic manifestation. Different extrahepatic manifestations for hepatitis C was described; these extend from strong associations as in mixed cryoglobulinemia to others were anecdotal finding as vitiligo was reported. The list of extrahepatic manifestations of hepatitis $\mathrm{C}$ is extending. In this review we tried to shade the light on this expanding list.

\section{INTRODUCTION}

Extrahepatic manifestations (EHM) of hepatitis $\mathrm{C}$ virus (HCV) include diseases that affect organs other than the liver, and it may be the first presentation of $\mathrm{HCV}$ infection. Association between them was first described in 1990 with cryoglobulinemia [1]. Subsequently, nearly all organs were reported as kidney, skin and thyroid [2]. Up to $40-74 \%$ of patients infected with $\mathrm{HCV}$ might develop at least one extrahepatic manifestation during the course of their disease [3].

\section{PATHOGENESIS}

$\mathrm{HCV}$ replicates within extrahepatic tissues with expression of viral proteins, leading to EHM. An important feature of HCV is that the virus avoids immune elimination. The consequences are chronic infection, accumulation of immune complexes and auto-immune phenomena. HCV shows lymphotropism in addition to the hepatotropism, which is responsible for many EHM [4].

\section{I) Autoimmunity}

- Auto antibodies production

The cellular components leak from the persistent destruction of the infected cells. About 20\% with hepatitis $\mathrm{C}$ patients are ANA positive [5].

- The molecular mimicry between HCV and auto antigens [6].

- Abnormality of lymphocytic cells

$\mathrm{HCV}$ infection and proliferation within lymphocytes leads to functional alteration of lymphocyte and production of excessive auto antibodies and cryoglobulins [7].

\section{II) HCV infection of cells other than hepatocytes}

$\mathrm{HCV}$ binds several cell surface receptors. Cell tropism required for $\mathrm{HCV}$ genome replication are not well characterized [8].

Classification of EHM of hepatitis C virus

EHM classified into four groups according to degree of association recorded to $\mathrm{HCV}$ infection. 
Table (1): EHM Classification [9].

\begin{tabular}{|c|c|c|c|}
\hline Group A & Group B & Group C & Group D \\
\hline Strong association & $\begin{array}{l}\text { Significant } \\
\text { association }\end{array}$ & $\begin{array}{l}\text { Similar pathologic } \\
\text { nature }\end{array}$ & Anecdotal \\
\hline $\begin{array}{l}\text { - Mixed } \\
\text { cryoglobulinemia } \\
\text { - B-cell non-Hodgkin's } \\
\text { lymphoma }\end{array}$ & \begin{tabular}{|l} 
- Monoclonal \\
gammopathies \\
- Porphyria cutanea \\
tarda \\
- Lichen planus \\
- Diabetes mellitus
\end{tabular} & $\begin{array}{l}\text { - Autoimmune thyroiditis } \\
\text { - Thyroid cancer } \\
\text { - Sicca syndrome } \\
\text { - Idiopathic lung fibrosis } \\
\text { - Non cryoglobulinemic } \\
\text { nephropathies } \\
\text { - Erectile dysfunctions } \\
\text { - Carotid atherosclerosis } \\
\text { - Psychopathological } \\
\text { disorders }\end{array}$ & $\begin{array}{l}\text { - Psoriasis } \\
\text { - Peripheral/central neuropathies } \\
\text { - Rheumatoid arthritis } \\
\text { - Polyarteritis nodosa } \\
\text { - Behcet's syndrome } \\
\text { - dermatomyositis } \\
\text { - Fibromyalgia } \\
\text { - Chronic pruritus } \\
\text { - Kaposi's pseudosarcoma } \\
\text { - Vitiligo } \\
\text { - Cardiomyopathies } \\
\text { - Mooren corneal ulcer } \\
\text {-Necrolytic acral erythema }\end{array}$ \\
\hline
\end{tabular}

\section{Mixed cryoglobulinemia (MC)}

Is a systemic vasculitis characterized by the deposition of circulating immuno-complexes in small and medium-sized blood vessels resulting in clinical manifestations [10].

\section{Cryoglobulins}

Are serum proteins that precipitate at low temperatures and then redissolve during incubation at $37^{\circ} \mathrm{C}$. Different categories have been described that refer to their different immunologic compositions [11].

Table (2): Classification of cryoglobulins [12].

\begin{tabular}{|l|l|l|}
\hline \multicolumn{1}{|c|}{ Type } & \multicolumn{1}{|c|}{ Clonality of immunoglobulins } & \multicolumn{1}{c|}{ Associated diseases } \\
\hline I & Monoclonal immunoglobulins (IgM or IgG) & Lymphoproliferative diseases \\
\hline III (mixed) & $\begin{array}{l}\text { Polyclonal immunoglobulins (mainly IgG) plus } \\
\text { monoclonal } \\
\text { Immunoglobulins (IgM, IgG, IgA) }\end{array}$ & Mixed cryoglobulinemia \\
\hline
\end{tabular}

\section{Prevalence}

Although overt symptoms of cryoglobulinemic vasculitis develop in only approximately $5 \%$ of chronic HCV infection cases, circulating mixed cryoglobulin complexes are much more common in about $40-50 \%$ in chronic $\mathrm{HCV}$-infected patients [10].

Significant geographic diversity appears among patients with HCV-related MC, with greater prevalence in southern Europe compared to northern Europe and North America, with high values (over 90\%) in the Mediterranean area [13].

\section{Pathogenesis}

The Circulating immune complexes in $\mathrm{HCV}$ related $\mathrm{MC}$ comprises hepatitis $\mathrm{C}$ virions, IgGIgM-RF antibody complexes and complement [14].
The common hypothesis regarding HCV-related cryoglobulinemia is the chronic antigenic stimulation of the humoral immune system, which facilitates clonal B-lymphocyte expansion [15].

Other hypotheses:

-Chronic HCV infection of $\mathrm{B}$ cells and Bcl-2 activation (protoncogene) which increase B cell survival by inhibiting apoptosis [16].

-Interaction of HCV E2 envelope protein with the cell surface glycoprotein CD81 that is present on $\mathrm{B}$ cells as well as on hepatocyte reduces the threshold for B-cell activation. HCV-specific proteins also demonstrate molecular mimicry with auto antigens. NS5A and NS core proteins can simulate host auto antigens, possibly resulting in B-lymphocyte activation and auto antibody production which may allow cross- 
reaction between a virus-associated epitope and IgG auto antigen [17].

-Cytokine, B-cell activating factor of the tumor necrosis factor family (BAFF) also known as Blymphocyte stimulators as zTNF4 were found in high levels in patients with $\mathrm{MC}$ associated $\mathrm{HCV}$ [18].

\section{Correlation with Liver Disease}

$\mathrm{MC}$ tends to correlate with duration of $\mathrm{HCV}$ infection and older age. However, cryoglobulinemia in the serum of HCV patients has been associated with increased risk of advanced fibrosis, the severity of hepatic steatosis on liver biopsy and cirrhosis, irrespective of age or disease duration [19].

\section{Clinical features of MC}

More common symptoms are general malaise, arthralgia and weakness. Arthralgia without arthritis is common, typically affecting the proximal interphalangeal joints of the hands, metacarpophalangeal joints, knees, and hips [20].

\section{1- Skin}

Commonly involved (95\% of cases) with a cutaneous vasculitis ranging from palpable purpura (leukocytoklastic vasculitis) and petechiae in the lower extremities to large necrotic ulcerations. Raynaud's phenomenon occurs in up to $1 / 3$ of cases and involves hands, feet, lips, ears, and the tip of the nose [20]

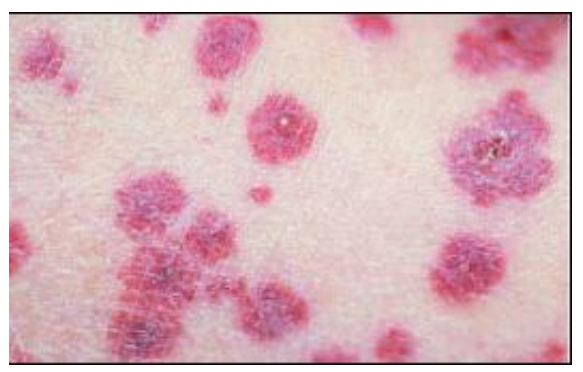

Figure (1): Leukocytoclastic vasculitis [21]

\section{2- Kidney}

Frequently involved (35-60\%) and Membranous proliferative glomerulonephritis (MPGN) is the prevalent type associated with MC [22]. Anti$\mathrm{HCV}-\mathrm{Ab}$ is universal in patients with both cryoglobulinemia and MPGN. HCV-RNA is present in nearly $81 \%$ of MC related MPGN versus only $25 \%$ of cases of noncryoglobulinemic MPGN [23].

Less often $\mathrm{HCV}$ causes focal segmental glomerular sclerosis or membranous or proliferative glomerulonephritis [24]. The course of renal pathology is variable. A clinical regression is observed in $10-15 \%$ of patients with nephritic syndrome. In $30 \%$ of cases, the clinical trend is slow and renal function is maintained for many years. In $20 \%$ of patients the disease is characterized by recurrent episodes of nephritic syndrome. In less than $15 \%$ of $\mathrm{MC}$, dialysis is required [25].

\section{3- Peripheral neuropathy}

Mostly sensory and is characterized by numbness, burning, needles and pins sensations most often in the hands and feet [26].

\section{4- Central nervous system (CNS)}

CNS involvement in patients with HCV-positive $\mathrm{MC}$ is rare [27].

\section{5-Other manifestations}

Rarely other organs as lungs, GIT and heart may be involved, secondary to vasculitis has been reported [28].

Diagnosis of MC

Classification criteria for MC diagnosis include clinical and serological data. Some patients with chronic HCV infection may show complete or even incomplete forms of MC. In the latter, a strict follow up of the patient is required [29].

Table (3): Criteria for the diagnosis and classification of patients with MC [29].

\begin{tabular}{|l|l|l|l|}
\hline Criteria & \multicolumn{1}{|c|}{ Serologic } & \multicolumn{1}{c|}{ Pathologic } & \multicolumn{1}{c|}{ Clinical } \\
\hline Major & $\begin{array}{l}\text { Mixed cryoglobulins } \\
\text { Low C4 }\end{array}$ & Leukocytoclastic vasculitis & Purpura \\
\hline Minor & $\begin{array}{l}\text { RF }+, \text { HBV+ } \\
\text { HCVing }\end{array}$ & $\begin{array}{l}\text { Clonal B-cell infiltrates } \\
\text { (liver and/ or bone marrow) }\end{array}$ & $\begin{array}{l}\text { Chronic hepatitis, MPGN, } \\
\text { peripheral } \\
\text { neuropathy, skin ulcers }\end{array}$ \\
\hline
\end{tabular}

"Definite" Mixed Cryoglobulinemia Syndrome

1) Serum mixed cryoglobulins ( \pm low $\mathrm{C} 4)+$ purpura + leukocytoclastic vasculitis
2) Serum mixed cryoglobulins $( \pm$ low $\mathrm{C} 4)+2$ minor clinical symptoms +2 minor serological/pathologic findings [29]. 
Biopsy of skin lesions shows immunecomplexes vasculitis of small vessels with mononuclear infiltration. $\mathrm{HCV}$ antigens are detected in skin lesions in $40 \%$ of cases [30].

Renal biopsy demonstrates deposits of IgGIgM-RF activity and C3 in capillary loops. The most characteristic findings are the capillary thrombi consisting of precipitated cryoglobulins at light microscopy [31].

Nerve Biopsy shows show axonal degeneration, differential fascicular loss of axons, demyelinization signs and small-vessel vasculitis with mononuclear cell infiltrates in the perivascular area [32].

\section{Treatment of MC}

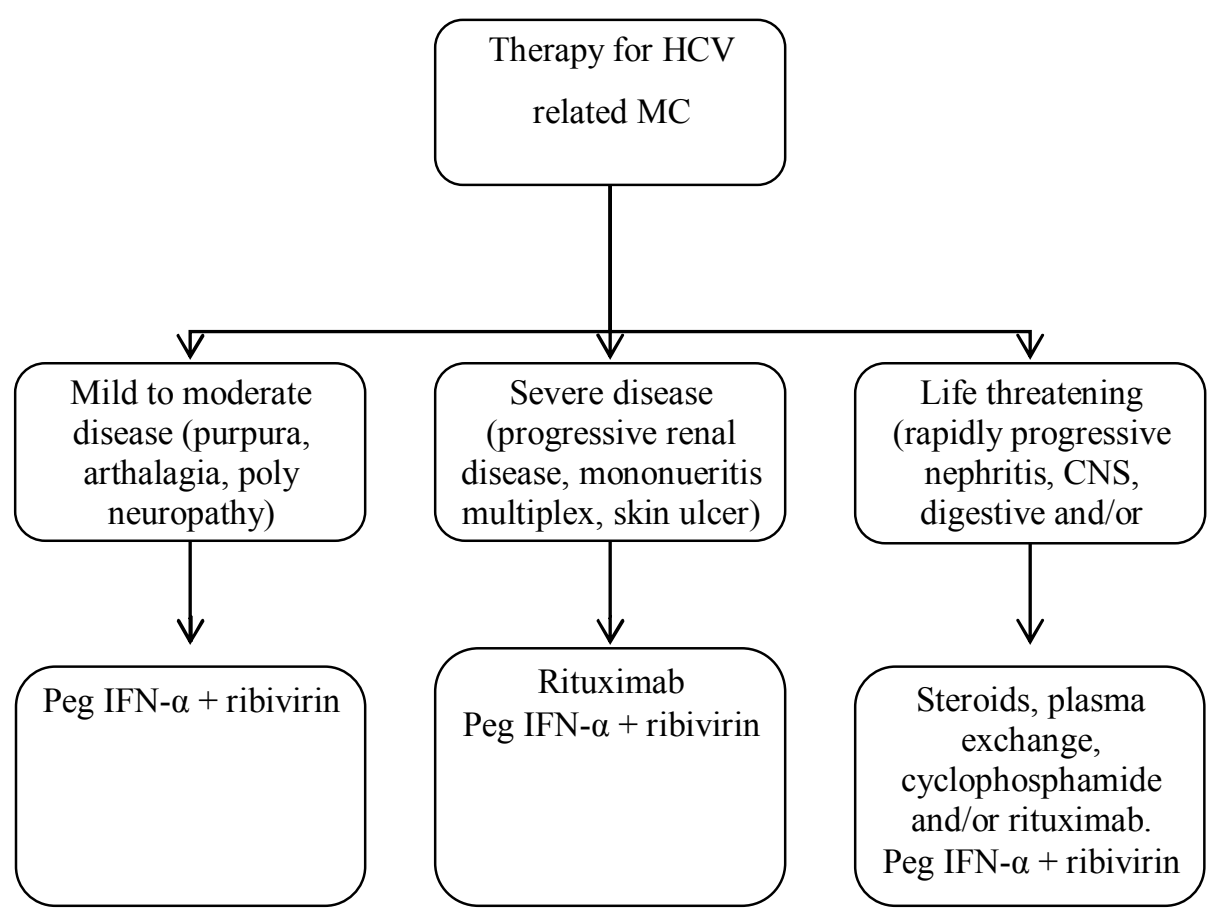

Figure (2): Therapeutic strategies in patients with HCV-associated MC [33].

Therapy should be initiated for patients with symptomatic $\mathrm{MC}$, and is directed to both the virus and the immune-mediated inflammation [34].

\section{Plasma exchange (PE)}

$\mathrm{PE}$ is the removal of circulating immunocomplexes. Immunosuppressive therapy is usually associated with plasma exchange in order to avoid the rebound increase in cryoglobulinaemia that is commonly seen after discontinuation of exchange [35]. When used in combination with anti-HCV treatment, plasmapheresis did not modify the virological response [36].

\section{Antiviral Therapy}

Antiviral therapy is the mainstay of long-term control of both the hepatic and extrahepatic manifestations. It should be started after systemic vasculitis has come under initial control, because the disease can be exacerbated with the initiation of interferon therapy in some patients [37].

\section{IFN alfa monotherapy:}

Can reduce viral load and induce clinical improvement in MC. However, relapse within a few months of therapy withdrawal is common [38].

\section{Pegylated IFN-a:}

Results showed improving tolerability and giving good outcomes [39].

\section{Ribavirin monotherapy:}

Ribavirin may be effective in IFN- $\alpha$ intolerant patient with symptomatic HCV cryoglobulinaemia. Its use in patients with renal involvement should be monitored carefully and the effect is not sustained when therapy is discontinued [38]. 


\section{Therapy with PEG-IFN and ribavirin:}

Has significantly increased sustained virologic response to therapy [40]. Patients with HCV-MC who achieve SVR also achieve prolonged clinical remission. The current treatment duration in HCV-MC is 12 months for all genotypes [19].

\section{Immunosuppressive drugs:}

Cyclophosfamid,

chlorambucil,

and azathioprine

It can be used in life threatening organ involvement when there is no response to steroids. These drugs have severe side effects and can lead to liver disease progression due to their immnuosuppresive effect [41].

\section{Rituximab}

Its action includes antibody dependent cellular cytotoxicity, complement dependent cytotoxicity, and apoptosis effective in reducing IgM production [42]. Significant reductions in serum levels of IgM, cryoglobulins, and RF were demonstrated with a rise in C4 levels [43].

Treatment with rituximab at a dose of 375 $\mathrm{mg} / \mathrm{m} 2$ weekly for 4 consecutive weeks, $80 \%$ of patients achieve complete response within 4 months of therapy, with their skin, joint, and neuromuscular symptoms showing strong response to treatment. Therapy with rituximab also allows most patients to discontinue maintenance therapy with corticosteroids [44]. Its combination with antiviral is necessary and duration of its use lasting from 6-12 months according to response. The continued efficacy and safety of repeated therapy in HCV-MC needs further investigations [33].

\section{A low antigen content diets (LAC diet)}

Lac-diet consists of a diet with a reduced content of alimentary macromolecules with high antigenic properties, are prescribed in order to help immunocomplexes clearance. It prescribed at the initial stage of disease, to reducing the antigen load to the reticulo-endothelial system, thus allowing a more efficient removal of cryoglobulins. This diet can improve minor manifestations of the MC [9].

\section{The end of therapy criteria}

These criteria are needed for patients with cryoglobulinemia.
-Undetectable serum HCV and cryoglobulins,

-Clearance of monoclonal RF producing cells from the blood by $\mathrm{B}$ cell clonal expansion analysis, and

-Clearance of $\mathrm{HCV}$ and lymphoid aggregates in the liver [45].

It is not clear whether Peg-IFN and ribavirin therapy can produce long-term remission of HCV-MC and whether achieving SVR means that patients are free from the risk of relapse of their HCV-MC symptoms [46]. The optimum length of treatment remains unknown, and severe cases may need long term or even life long therapy [47].

\section{Lymphoproliferative disorders (LPD)}

In HCV infected persons, LPD may be as progress of $\mathrm{MC}$ in up to $11 \%$ of cases (intermediary disorder) or occurred independently in patients without MC [48]. A frequent association reported between $\mathrm{HCV}$ infection and non-Hodgkin lymphoma [49].

\section{Prevalence}

The prevalence of HCV infection in B-cell NHL has given conflicting results. Several countries data ranges from $9 \%$ to $37 \%$ [50] and $90 \%$ of NHL patients have cryoglobulinemia [51]. Low grade lymphomas are more frequently associated with HCV [52]. The association between HCV and NHL is strongest in geographic areas with the highest prevalence of the viral infection [53].

\section{Pathogenesis}

The mechanism may be due to long term $\mathrm{HCV}$ infection, resulting in clonal $\mathrm{B}$ cell expansion of immunoglobulin (cryoglobulin) secreting lymphocytes, also a combination of a mutation agents like factors (genetic, environmental, immunological) result in activation of oncogenes and resulting in NHL. Another possibility is the inhibition of apoptosis of $\mathrm{HCV}$ infected lymphocytes by over-expression of the bcl2, and a second mutation (myc oncogene) may lead to the development of lymphoma [54]. This data suggest that the multi step lymphomagenetic cascade may have points of no-return, making LPD progressively independent from $\mathrm{HCV}$ infection [55]. 


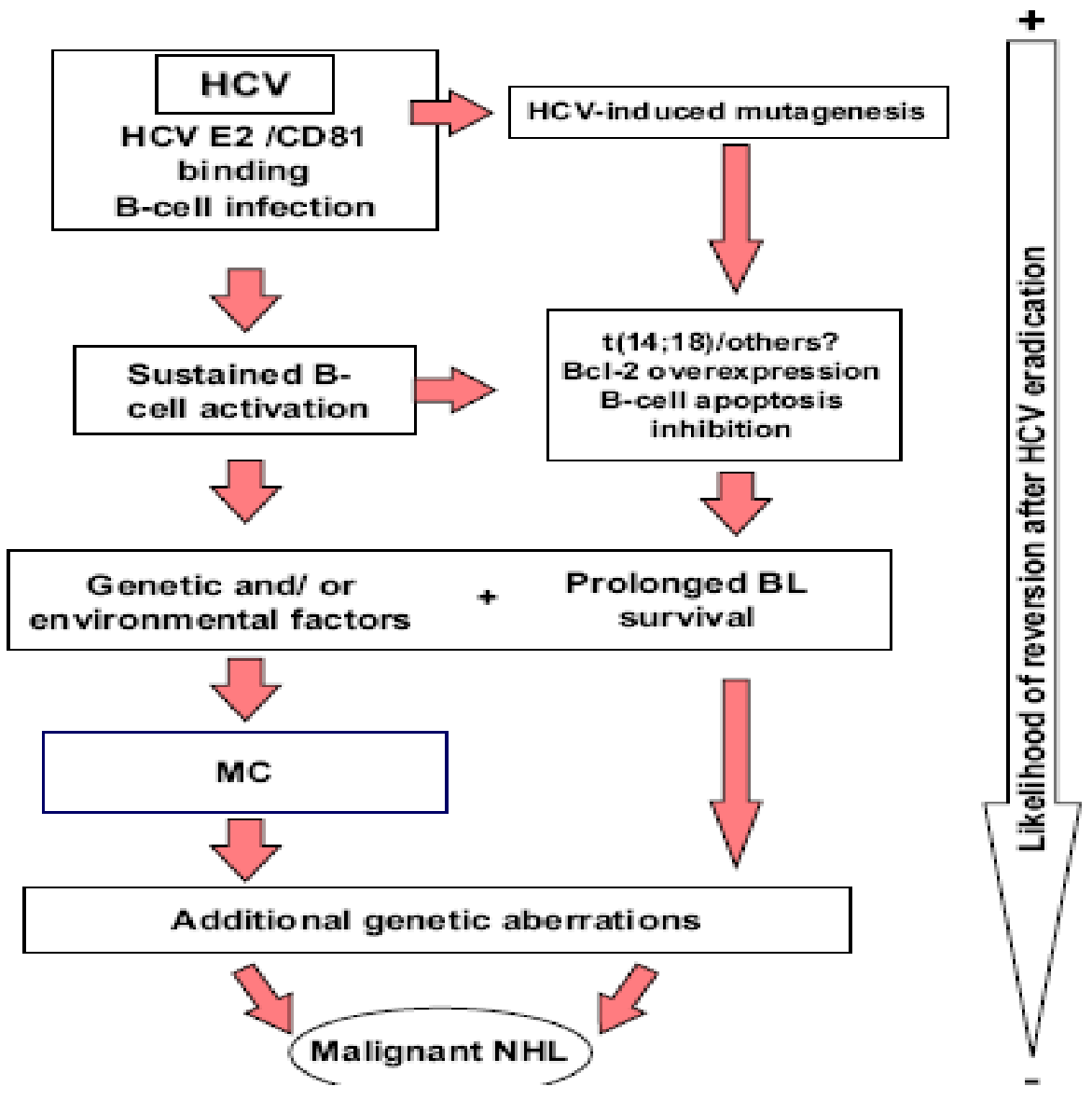

Figure (3): Pathogenesis of hepatitis C virus-related lymphoproliferative disorders [55].

\section{Classification of LPD}

All types of lymphoid malignancy can be found in patients with $\mathrm{HCV}$ infection but, the strongest association is noticed with B-cell derived NHL [56].

\section{Non- Hodgkin Lymphoma (NHL)}

According to the Revised European-American Lymphoma (REAL) classification/World Health Organization (WHO), the most frequent histological subtypes observed is: lymphoplasmacytic $(29 \%)$, diffuse large B-cell $(27 \%)$, follicular (16\%), marginal zone $(10 \%)$ and mantle cell (7\%) lymphomas [57]. Approximately $65 \%$ of $\mathrm{HCV}$-related NHL shows extra nodal involvement [58] . A strong link between $\mathrm{HCV}$ infection and mucosa-associated lymphoid tissue (MALT) lymphoma, HCV RNA has been isolated in the gastric mucosa of patients with MALT lymphoma [59].

Splenic marginal zone lymphoma shows a particularly high incidence $(35 \%)$ of $\mathrm{HCV}$ infection, and is related to the hypothesis that Bcell NHL arises selectively from the marginal zone B-cell [60].

\section{Monoclonal Gammopathies:-}

Other LPDs reported in the course of $\mathrm{HCV}$ infection are monoclonal gammopathies (MG). Usually they are gammopathies IgM/Kappa. In most patients with $\mathrm{HCV}, \mathrm{MG}$ was classified as monoclonal gammopathies of uncertain significance, which are present in up to $11 \%$ patients with HCV infection without cryoglobulins [61], Whereas a few patients who have $\mathrm{HCV}$ with $\mathrm{MG}$ can be considered as myeloma according to their clinicopathologic characteristics [62].

Soresi et al., [63] found significant relationship between abdominal lymphadenopathy and histological abnormalities of the liver, presence of HCV RNA in the serum and gamma globulin levels indicating a possible interaction between viral antigens and the immune system.

\section{Treatment of LPD}

\section{Antiviral Therapy}

It is an attractive therapy for low-grade HCVpositive NHL, but in intermediate and high-grade NHL, chemotherapy is necessary while antiviral 
treatment possibly could represent a maintenance therapy [64].

Treatment with IFN +/- ribavirin is effective in $\mathrm{HCV}$-associated indolent and marginal zone lymphomas which are mostly occurred with cryoglobulinemia [65]. A complete remission with IFN and ribavirin has been also reported in a patient with $\mathrm{HCV}$-associated mantle cell NHL resistant to chemotherapy and rituximab [66] . In addition, regression of clonal proliferation in response to antiviral treatment was shown to be associated clearly with virological response [67]. Although of SVR, the rearrangement of the monoclonal immunoglobulin genes persistently was detected in the blood even after a complete hematological response [68].

\section{Chemotherapy}

Rituximab has become part of the standard treatment regimens used in a variety of B-cell NHL [69]. The use of rituximab in HCVassociated NHL, in monotherapy or in combination with antiviral treatment and/or chemotherapy, appears very promising, particularly in the setting of low-grade NHL, where rituximab monotherapy has been proposed as first-line treatment [70]. However Complications of NHL therapy with rituximab, manifested by increased levels of HCV RNA in blood have been reported [71].

\section{Porphyria cutanea tarda (PCT)}

Is a metabolic disease caused by the reduction of hepatic uroporphyrinogen decarboxylase activity, resulting in an over production and deposition of the protein uroporphyrinogen in the blood and urine of patients [72].

\section{Prevalence}

$\mathrm{HCV}$ infection in patients with porphyria is high, $40-50 \%$ depending on the country [73]. A strong association (50-90\%) has been demonstrated between sporadic PCT cases and HCV infection in patients from the Mediterranean basin, Japan and the United States [74].

\section{Pathogenesis}

HCV does not appear to induce alteration of porphyrin metabolism but it may induce the disease in genetically predisposed individuals [75]. PCT might be related to HCV induced hepatic iron overload. Patients with PCT who are of northern European origin were also found to have increased prevalence of HFE gene mutation, which is responsible of hereditary hemochromatosis [76]. Cacoub et al., [3] suggested that cirrhosis may play a role in its development, reporting that the highest rates of PCT were in patients with HCV related liver cirrhosis.

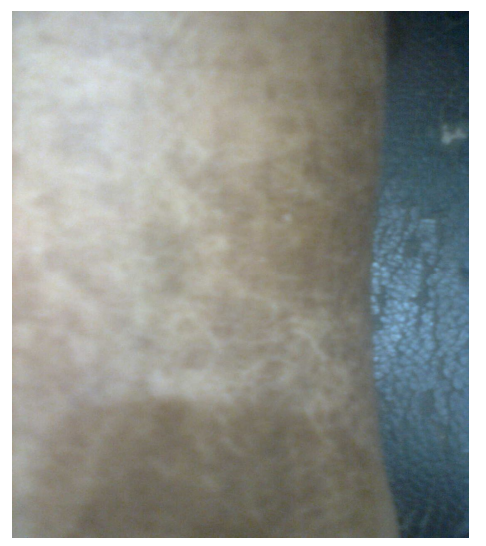

Figure (4): Lower limb pigmentation in $\mathrm{HCV}$ cirrhosis

\section{Clinical features}

Photosensitivity, skin fragility, bruising and vesicles and bullae that may become hemorrhagic are the main manifestations of PCT. Chronic findings include hypo or hyperpigmentation, alopecia, hirsutism and skin thickening [25].
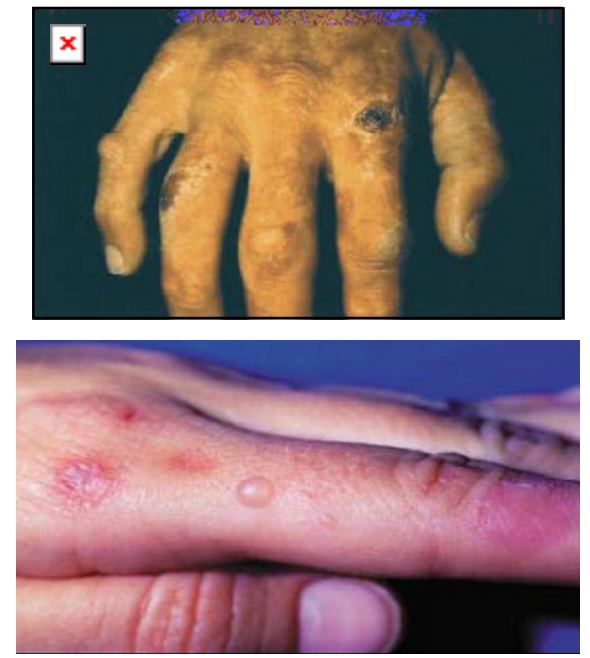

Figure (5): Porphyria Cutanea Tarda [77].

\section{Diagnosis}

Gross examination of the urine can provide a valuable clue, because urine of PCT patients is red to brown in natural light and pink to red in fluorescent light. Confirmation requires measurement of porphyrin levels in a 24-hour urine collection [78]. It is recommended that all patients with PCT should be screened for $\mathrm{HCV}$ infection [79]. 


\section{Treatment}

Vigorous iron removal by dietary restriction of foods rich in iron, avoidance of alcohol and estrogen use and phlebotomy to remove iron. The next step is the treatment of chronic hepatitis $\mathrm{C}$ with interferon and ribavirin. Antimalarial drugs like chloroquine have been used in the treatment of PCT [80].

\section{Lichen planus (LP)}

Is a recurrent pruritic eruption characterized by flat-topped violaceous papules that can develop on any skin site (arms, trunk, genitalia, nails and scalp), and mucosal membranes mainly oral mucosa [72]. The presence of HCV RNA in gingival crevicular fluid might have possibly reflected the viral presence in mucosal epithelial cells [81].
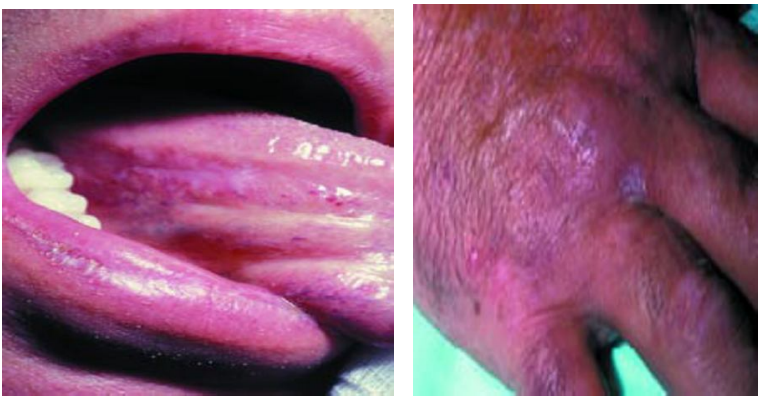

Figure (6): Oral and skin LP [82].

\section{Pathogenesis}

$\mathrm{HCV}$ infection may induce autoantibodies against the product of a host gene termed GOR which shares several amino acids with the core gene product of $\mathrm{HCV}$ [83]. HCV may play a pathogenic role by stimulating LP in genetically succeptible patients [84].

\section{Treatment}

LP responds variably to interferon treatment: both improvement and exacerbation of symptoms have been reported [85].

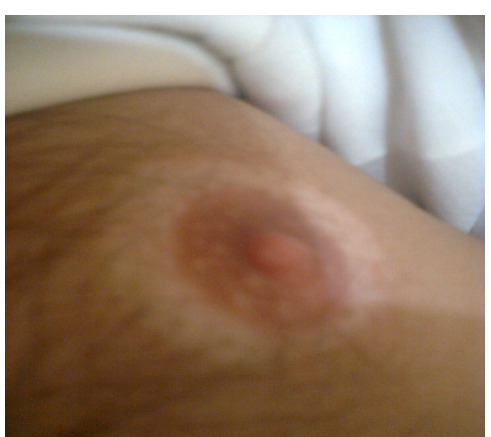

Figure (7): Circum-areola vitiligo in chronic $\mathrm{HCV}$

\section{Diabetes mellitus}

DM is found more commonly in patients with chronic HCV infection than in the general population. HCV alone acts as a risk factor for DM, independent from liver disease [86].

\section{Prevalence}

$\mathrm{DM}$ in patients with cirrhosis due to $\mathrm{HCV}$ is $25 \%$, in alcoholic liver disease is $19 \%$ and in patients with cirrhosis due to cholestatic liver disease is $13 \%$. It was found that the countries which have high prevalence of $\mathrm{HCV}$ infection showed increased risk of type 2 diabetes, from 2 to 10 fold compared with liver disease control subjects [87].

$\mathrm{HCV}$ positive patients having liver transplantation, reported from 4 to 8 folds increased prevalence of diabetes as compared with patients with other viral or cholestatic liver disease one year after liver transplantation[88]. $\mathrm{HCV}$ infection provided a more than three folds increased risk of developing diabetes in individuals aged more than $40 \mathrm{y}$ and two fold for those aged less than 40 years [89].

\section{Pathogenesis}

There is evidence that HCV-positive diabetic patients have both peripheral insulin resistance and B-cell dysfunction [90]. TNF- $\alpha$ has been shown to inhibit insulin-stimulated tyrosine phosphorylation of insulin receptor and insulin receptor substrate 1 in adiopocytes, stimulate lipolysis, and increase serum FFA leading to insulin resistance and down regulate of genes in adipocytes encoding proteins such as insulin receptor substrate 1, glucose transporter-4, peroxisome proliferators-activated receptors, and adiponectin. In addition, TNF- $\alpha$ may reduce Bcell function by direct toxic effects. TNF- $\alpha$ receptors were found in higher levels in diabetic HCV patients than non diabetic HCV patients [91]. Also, postmortem studies expose that $\mathrm{HCV}$ replicates in the pancreas [92].

\section{$\mathrm{HCV}$ genotypes and diabetes}

In chronic $\mathrm{HCV}$ genotype 1 patients, insulin resistance and overt diabetes are major determinants of advanced fibrosis, regardless of the degree of steatosis [93]. Chehadeh et al., [94] made two observations that support direct pathogenic role of $\mathrm{HCV}$ genotype 4. First, in presence of $\mathrm{HCV}$ infection, diabetes occurs at a significantly lower median age with less prevalence of obesity than those diabetic $\mathrm{HCV}$ - 
negative patients. Second, follow up of $\mathrm{HCV}$ patients who had received antiviral drugs revealed a significant decrease of glucose level among diabetic patients who achieved SVR.

\section{Treatment}

The role of antiviral therapy is debated due to association between interferon and the induction of anti-pancreas auto anti bodies in some patients [95]. But clinical trials report improvement in measures of glucose metabolism after antiviral treatment [90].

\section{Thyroid dysfunction}

The direct link between HCV infection and thyroid diseases is unclear, but thyroid disease usually hypothyroidism is more commonly seen in people with $\mathrm{HCV}$ than in the general population [95]. Antiviral therapy can also induce thyroid disease or may unmask autoimmune disease as Graves disease. In about $50 \%$ of people who develop therapy related hypothyroidism, thyroid function will return to normal when treatment is stopped [97].

\section{The prevalence}

About $13 \%$ of $\mathrm{HCV}$ infected patients have hypothyroidism and up to $25 \%$ have thyroid antibodies. Papillary thyroid cancer was reported in patients with HCV infection [98].

\section{Pathogenesis}

It was suggested through molecular mimicry between viral antigens and self-antigens [99].

\section{Treatment}

The principal risk factor for developing thyroid disease in the course of antiviral therapy is the previous positivity for anti-thyroid antibodies (anti-peroxidase) especially in older women [100] and patients who may be genetically susceptible [101].

Antiviral therapy is contraindicated in patients with thyroid disease not controlled but the presence of autoantibodies against thyroid without clinical manifestations is a relative contraindication to antiviral therapy. In the case of a good therapeutical control of a preexistent thyroid disease, antiviral therapy can be continued. During treatment, frequent controlled tests for thyroid functionality should be performed [25].

\section{Lung involvement}

Idiopathic pulmonary fibrosis, diffuse alveolar damage, desquamative interstitial pneumonia, bronchiolitis obliterans organizing pneumonia, pulmonary vascuilitis and acute respiratory distress syndrome have been described in only anecdotal case reports [102].

\section{Idiopathic pulmonary fibrosis}

Is a chronic inflammatory interstitial lung disease characterized by an accumulation of alveolar macrophages and neutrophils in the lower respiratory tract, parenchymal injury, and interstitial fibrosis [103].

\section{Pathogenesis}

HCV may trigger a subclinical lymphocyte alveolitis [104]. Age, liver cirrhosis and smoking enhance the development of IPF in patients with chronic hepatitis C infection [105].

\section{Treatment}

Treatment with corticosteroid and antiviral therapy in most cases of lung involvement associated HCV mainly have no good results [103].

\section{Noncryoglobulinemic nephropathies}

$\mathrm{HCV}$ associated renal disease including membranous, membranoproliferative and acute proliferative glomerular disease are well documented [106]. HCV related glomerulonephritis, must be considered before the onset of therapy with antiviral and/or immunosuppressive agents by the histological demonstration and classification of inflammatory glomerular damage in the renal biopsy [26]. About $30 \%$ of patients have complete or partial remission of their renal disease, $30 \%$ suffer from intermittent exacerbations and remissions, 30\% have an indolent course and 10\% may develop chronic renal failure [107].

\section{Erectile Dysfunction}

Ferri et al., [15] diagnosed erectile dysfunction in 39\% HCV-positive patients and in $14 \%$ control subjects. Erectile dysfunction was more common in patients with cryoglobulinemic vasculitis than in those with chronic $\mathrm{HCV}$ infection. Plasma levels of total and free testosterone were generally lower in HCVpositive patients, but they were significantly lower in patients with erectile dysfunction versus those without. However, it is also possible, that 
antiviral treatment may improve erectile function in some patients.

\section{Psychopathological disorders}

Neuropsychiatric symptoms as malaise, fatigue and depressive symptoms have been reported during both acute and chronic stages of hepatitis $\mathrm{C}$ and IFN- $\alpha$ treatment [108]. Patients, have a low quality of life and decreased cognitive ability [109].

\section{Prevalence}

Depression was reported in $2 \%-30 \%$ of hepatitis C patients [110].

\section{Pathogenesis}

It has been supposed that the virus may cause direct cerebral dysfunction by an unknown mechanism [111]. Plasma tryptophan and kynurenine content in blood, together with indoleamine 2, 3-dioxygenase activity in macrophages, was evaluated in whom had mild HCV related chronic liver disease. Serum tryptophan concentrations were lower than those of healthy subjects or patients who had chronic HBV infection, and were associated with high levels of anxiety and depression [112,113].

\section{Treatment}

Antidepressants can help in the reduction of depression associated with hepatitis $\mathrm{C}$ treatment which should be under supervision [109].

\section{Peripheral neuropathy (PN)}

Up to $15.3 \%$ of the $\mathrm{HCV}$ population has $\mathrm{PN}$. The exact cause of $\mathrm{HCV}$ related $\mathrm{PN}$ is not completely understood. Some theories suggest that HCV related PN is by HCV RNA deposits in blood vessels that supply oxygen to the nerves, $\mathrm{HCV}$ infection of the nerves, an inflammation process in the nerves, and/or HCV related immune disorder [114].

The best initial treatment option in patients with slight to moderate neuropathy is corticosteroids and/or IFN- $\alpha$ monotherapy [115]. However, treatment with interferon has produced mixed results and there is a chance that interferon could exacerbate PN. In patients who do not respond, combined antiviral therapy or intravenous immunoglobulins should be considered. The best option in severe or refractory cases is plasmapheresis [26].

\section{Psoriasis}

$\mathrm{HCV}$ is suggested to be one of the triggering factors of psoriasis [116]. The management of patients with psoriasis and concomitant $\mathrm{HCV}$ is often difficult because treatments for hepatitis $\mathrm{C}$ may trigger or exacerbate psoriasis. In addition, most systemic therapies for psoriasis, including immunosuppressants are relatively contraindicated in HCV infection [117]. Etanercept (TNF inhibitor) has an excellent safety profile for the treatment of severe psoriasis with psoriatic arthritis and concomitant hepatitis $\mathrm{C}$ virus [118].

\section{Arthralgia}

Arthralgia is common in patients with chronic $\mathrm{HCV}$ infection and is reported in $19 \%$ of $\mathrm{HCV}$ patients [3].

\section{HCV-related Arthritis}

This includes arthritis associated with or without the presence of MC [119]. Overt arthritis occurs less frequently than arthralgia, with prevalence of less than $5 \%$ in patients with chronic $\mathrm{HCV}$ infection [26].

\section{Clinical Manifestations}

It commonly presented as rheumatoid like symmetrical inflammatory polyarthritis involving mainly small joints or less commonly as mono or oligoarthritis of large joints [21]. In about $2 / 3$ of the affected individuals, morning stiffness may be severe, resolving after more than an hour [120]. The presence of MC in patients with $\mathrm{HCV}$ infection consists of an intermittent, mono or oligoarticular, nondestructive arthritis affecting large and medium size joints [119].

\section{Differences between true $\mathrm{RA}$ disease and $\mathrm{HCV}$ related arthritis.}

Differentiation may be difficult. HCV related arthritis usually runs a relatively benign course that is typically non deforming [21]. Furthermore, unlike classic RA, ESR is elevated only in about half of the patients, articular bony erosions and subcutaneous nodules are absent [120].

Patients with HCV related arthritis are seropositive for RF. Therefore; anti keratin antibodies (AKA) are a useful marker to differentiate patients them. In a study AKA were detected in $69 \%$ of patients with RA compared to only $8 \%$ with HCV associated arthritis [121]. 
Positive HCV antibody and HCV RNA may be useful in distinguishing between $\mathrm{HCV}$ related arthritis and RA. Anti-cyclic citrullinated peptide antibodies were rarely present in $\mathrm{HCV}$ infected patients and were a reliable serological marker to discriminate between patients with $\mathrm{HCV}$ associated rheumatological manifestations and patients with rheumatoid arthritis [122].

\section{Pathogenesis}

$\mathrm{HCV}$ arthritis may be a part of MC or it may be directly or indirectly mediated by HCV infection. Direct invasion of synovial cells by the virus, causes local inflammatory response, cytokine induced disease or immune complex disease, particularly in genetically susceptible individuals [123]. HLA-DR4 histocompatibility antigen is significantly elevated in HCV infected patients with autoimmune diseases, including RA [124].

\section{Fibromyalgia (FM)}

Rivera et al., found that $15 \%$ of patients with FM have an HCV infection. IFN- $\alpha$ therapy can trigger FM symptoms in some patients [125].

\section{Pruritus (Itching)}

Pruritus is a presenting symptom in $20 \%$ of $\mathrm{HCV}$ infected patients and is associated with nonspecific lesions [126].

\section{Pathogenesis}

The pathogenesis is uncertain, but it may be caused by a portion of the hepatocyte cell membrane in association with a non-bile pruritogen acting as an opioid agonist [127]. However, subclinical cholestasis may also be a factor. Others causes may contribute in the pathogenesis of pruritus as accumulation of toxins as bilirubin, autoimmune conditions associated $\mathrm{HCV}$, side effects of interferon and ribavirin which causing dry skin [128].

\section{Necrolytic Acral Erythema}

Necrolytic acral erythema is a rare, but pathognomonic manifestation of $\mathrm{HCV}$. All cases are associated with HCV. Patients develop annular, hyperkeratotic, and violaceous plaques with raised scaly borders, although some lesions may be vesiculobullous. Lesions are acral in distribution. The pathogenesis of the disorder is unknown and the response to treatment is highly variable. Suggested treatments include amino acid and zinc, interferon-alpha, and ribavirin [129].

\section{Mooren corneal ulcer}

Chronic HCV virus infection is associated with Mooren type peripheral ulcerative keratitis. The cause appears to be due to cross reactivity between the HCV envelope protein and corneal antigen. All patients with Mooren type ulcers should be tested for HCV infection. Even when improvement is obtained with interferon alfa- $2 b$ treatment, however, continued follow up is important because relapse is common and repeated treatment may be effective [130].

\section{Cardiomyopathy}

Multiple studies have recorded relationship between HCV infection and the development of hypertrophic and dilated cardiomyopathy [131].

\section{Prevalence}

In a research project for the Study of Idiopathic Cardiomyopathy, HCV antibody was found in $10.6 \%$ with hypertrophic cardiomyopathy and $6.3 \%$ with dilated cardiomyopathy patients [131]. The association between chronic hepatitis $\mathrm{C}$ in various types of cardiomyopathy was originally reported in Japan up to $15 \%$. A study was done in Italy reported a prevalence of hepatitis $\mathrm{C}$ antibodies in patients with cardiomyopathy to be $3.9 \%$, [132]. A study from Brazil reported a prevalence of hepatitis $\mathrm{C}$ carrier state of $2.9 \%$ [133].

\section{Pathogenesis}

$\mathrm{HCV}$ induced cardiomyopathy is still controversial. The mechanisms by which this virus damages the myocardium have not been known. The development of HCV associated cardiomyopathy may take place in genetically susceptible individuals in whom viral, immunologic, and apoptotic mechanisms may act to produce myocardial damage. However, HCV may promote the development of cardiomyopathy by inducing continuous myocarditis, similar to other virus infections [134]. Some studies have proposed that hepatitis $\mathrm{C}$ virus (HCV) generates a tissue lesion mechanism similar to that caused by enterovirus and Coxsackie-B-virus, which are common in cases of myocarditis [135].

The physiopathology involves complex processes characterized by three phases:

- Infection of myocytes, and immunologically mediated cytotoxicity [136]. 
- Changing the entire heart anatomical and functional structure.

- Activation of an adaptive mechanism known as heart remodeling, which involves heart dilation and ventricular dysfunction in patients with CHF [137].

Okabe et al.,_ [138] have reported strands of HCV RNA in cardiac tissue from patients with chronic active myocarditis.

\section{Treatment}

The understanding of cardiomyopathy as an extrahepatic manifestation of $\mathrm{HCV}$ infection is of great importance because the treatments available for chronic hepatitis $\mathrm{C}$ at present are considered relative contraindicated in patients with myocardial dysfunction. However, if the cause is HCV associated cardiomyopathy may benefit from therapeutic managment that may result in eradication of the virus and reversal of myocardial dysfunction [139].

\section{HCV related Thrombocytopenia}

$\mathrm{HCV}$ antibodies were identified in $30 \%$ of patients with chronic idiopathic thrombocytopenia purpura [140].

\section{Pathogenesis}

Thrombocytopenia associated HCV may be present even in the absence of clinically evident liver disease or splenomegaly and may be wrongly diagnosed as ITP [140]. The detection of $\mathrm{HCV}$ in platelet and megakaryocytes make $\mathrm{HCV}$ related thrombocytopenia is probable cause. High affinity binding of $\mathrm{HCV}$ to platelet membrane with subsequent binding of anti-HCV antibody might lead to phagocytosis of platelets [141]. High rate of HCV RNA in HCV related thrombocytopenia than non thrombocytopenic patients was detected. Furthermore, HCV may be causative factor for the production of platelate associated immunoglobulin $G$ inducing thrombocytopenia in mechanism similar to idiopathic thrombocytopenia purpura (ITP) [142].

\section{Treatment}

Classical therapeutic approaches such as corticosteroid, antiviral therapy and intravenous immunoglobulin and splenectomy can be used. Disappearance of HCV RNA after IFN $\alpha$ associated with improvement of thrombocytopenia. Caution is recommended in thrombocytopenic patients treated with PEG-
IFN $\alpha$ and ribavirin when platelet count less than $50,000 / \mu 1$ as significant aggravation of thrombocytopenia may occur [143].. Platelet count can be decrease from $30-50 \%$ in patient who administrates interferon or peginterferon, so reduction of the dose must be if the platelet counts reach $50.000 / \mathrm{mm}$ and discontinuation of the antiviral therapy if the counts reach $25.000 / \mathrm{mm}$. Peg interferon alpha $2 \mathrm{a}$ can reduce the weekly dose from $180 \mu \mathrm{g}$ to 135 or even to $90 \mu \mathrm{g}$, and peg interferon alpha $2 \mathrm{~b}$ can reduce from $1.5 \mu \mathrm{g} / \mathrm{kg}$ to $1 \mu \mathrm{g} / \mathrm{kg}$ or even to $0.5 \mu \mathrm{g} / \mathrm{kg}$ [40].

\section{Human Recombinant Interleukin (IL)-II (Oprelvekin)}

Oprelvekin promoting proliferation and maturation of megakerocytes which can be used to stimulate increasing number of platelet count at dose of $5 \mu \mathrm{g} / \mathrm{kg} /$ day S.C for 7 days initially and if necessary during antiviral therapy maintainance by taking 1-3 doses per week [144].

\section{Elthrombopag}

Active thrombopoietin receptor agonist (Elthrombopag) may be applied before and during antiviral therapy in $\mathrm{HCV}$ related thrombocytopenia at dose 30,50 and $75 \mathrm{mg}$ lead to sustained increase of platelate count and it allows initiation and/or continuation of antiviral therapy [145].

Rituximib has promising therapeutic approach, especially in refractory cases or aggravating thrombocytopenia during the course of antiviral therapy [146].

\section{Funding: Non.}

Conflicts of Interest: Non.

Ethical Approval: Not needed.

\section{REFERENCES}

1. Pascual M, Perrin L, Giostra E, Schifferli J. Hepatitis $\mathrm{C}$ virus in patients with cryoglobulinemia type II. $J$ Infect Dis. 1990; 162: 569-70.

2. Zignego A, Brechot C. Extrahepatic manifestations of $\mathrm{HCV}$ infection: facts and controversies. J Hepatol. 1999; 31: 369-76.

3. Cacoub P, Renou C, Rosenthal E, Cohen P, Loury I, Loustaud-Ratti V, et al. Extrahepatic manifestations associated with hepatitis $C$ virus infection. A prospective multicenter study of 321 patients. Medicine 2000; 79: 47-56. 
4. Agnello V, De Rosa FG. Extrahepatic disease manifestations of $\mathrm{HCV}$ infection: some current issues. J Hepatol 2004; 40: 341-52.

5. Manns M, Obermayer-Straub P. Viral induction of autoimmunity: mechanisms and examples in hepatology. J Viral Hepatol 1997; 4: 42-47.

6. Moore P, Belvedere O, Orr A, Pieri K, LaFleur D, Feng P. Bly S: member of the tumor necrosis factor family and B lymphocyte stimulator. Science 1999; 285: 260-3.

7. Sansonno D, Cornacchiulo V, Iacobelli AR, Gatti P, Distasi M, Dammacco F. Hepatitis C virus infection and clonal B-cell expansion. Clin Exp Rheumatol 1996; 14: 45-50.

8. Favre D, Muellhaupt B. Potential cellular receptors involved in hepatitis $\mathrm{C}$ virus entry into cells. Lipids Health Dis 2005; 4: 9-14.

9. Zignego A, Ferri C, Pileri S, Caini P, Bianchi F. Extrahepatic manifestations of Hepatitis C Virus infection: a general overview and guidelines for a clinical approach. Dig Liver Dis 2007; 39: 2-17.

10. Lunel F, Musset L, Cacoub P, Frangeul L, Cresta $\mathrm{P}$, Perrin $\mathrm{M}$, et al. Cryoglobulinemia in chronic liver diseases: role of hepatitis $\mathrm{C}$ virus and liver damage. Gastroenterol 1994; 106: 1291-300.

11. Ferri C, Zignego A, Pileri S. Cryoglobulins. In: (Clinical hematology) by Young N, Gerson S, and High K. Mosby (MO): Elsevier 2005; 62536.

12. Brouet J, Clauvel J, Danon F, Klein M, Seligmann M. Biologic and clinical significance of cryoglobulins. A report of 86 cases. Am J Med 1974; 57: 775-88.

13. Sansonno D, Dammacco F. Hepatitis C virus, cryoglobulinemia, and vasculitis: immune complex relations. Lancet Infect Dis 2005; 5: 227-36.

14. Wang A, Wells J, Fudenberg H. Chemical analyses of cryoglobulins. Immunochemistry 1974; 11: 341-5.

15. Ferri C, Zignego A, Pileri S. Cryoglobulins. $J$ Clin Pathol 2002; 55: 4-13.

16. Zignego A, Ferri C, Giannelli F, Giannini C, Caini P, Monti M, et al. Prevalence of bcl-2 rearrangement in patients with hepatitis $C$ virusrelated mixed cryoglobulinemia with or without B-cell lymphomas. Ann Intern Med 2002; 137: 571-80.

17. De Re V, Sansonno D, Simula M, Caggiari L, Gasparotto D, Fabris M, et al. HCV-NS3 and IgG-Fc crossreactive IgM in patients with type II mixed cryoglobulinemia and B-cell clonal proliferations. Leukemia 2006; 20: 1145-54.

18. Fabris M, Quartuccio L, Sacco S, De Marchi G, Pozzato G, Mazzaro C, et al. B-lymphocyte stimulator (BLyS) up-regulation in mixed cryoglobulinaemia syndrome and hepatitis-C virus infection. Rheumatol 2007; 46: 37-43.

19. Saadoun D, Asselah T, Resche-Rigon M, Charlotte F, Bedossa P, Valla D, et al.
Cryoglobulinemia is associated with steatosis and fibrosis in chronic hepatitis C. Hepatol 2006; 43: 1337-45.

20. Dammacco F, Sansonno D, Piccoli C, Tucci F, Racanelli V. The cryoglobulins: an overview. Eur J Clin Invest 2001; 31: 628-38.

21. Remoroza R, Bonkovsky H. Extrahepatic manifestations of chronic hepatitis C. August 2003, available at http//: www.hcvadvocate.org

22. Johnson R, Gretch D, Yamabe H, Johnson R, Gretch D, Yamabe $H$, et al. Membranoproliferative glomerulonephritis associated with hepatitis $\mathrm{C}$ virus infection. $N$ Engl J Med 1993; 328: 465-70.

23. Misiani R, Bellavita P, Fenili D, Borelli G, Marchesi D, Massazza M. Hepatitis C infection in patients with essential mixed cryoglobulinemia. Ann Intern Med 1992; 117 : 573-77.

24. Tarantino A, Campise M, Banfi G, Confalonieri R, Bucci A, Montoli A. Long-term predictors of survival in essential mixed cryoglobulinemic glomerulonephritis. Kidney Int 1995; 47: 618-23.

25. Galossi Al, Guarisco R, Bellis L, Puoti C. Extrahepatic manifestations of chronic $\mathrm{HCV}$ infection. J Gastrointestin Liver Dis 2007; 16: 65-73.

26. Ramos-Casals M, Trejo O, Garcia-Carrasco M, Font J. Therapeutic management of extrahepatic manifestations in patients with chronic hepatitis C virus infection. Rheumatol 2003; 42: 818-28.

27. Casato M, Saadun D, Marchetti A, Limal N, Pic, C, Pantano P, et al. Central nervous system involvement in hepatitis $\mathrm{C}$ virus cryoglobulinemia vasculitis: a multicenter casecontrol study using magnetic resonance imaging and neuropsychological tests. J Rheumatol 2005; 32: 484-8.

28. Moschella C, Palmieri I, Bartolucci P, Assenza M, Maiuolo A, Modini, C. Spontaneous rectus sheath haematoma in $\mathrm{HCV}$ mixed cryoglobulinemia requiring emergency treatment (case report). G Chir 2002; 23: 331-33.

29. Ferri C, Sebastiani M, Giuggioli D, Cazzato M, Longombardo G, Antonelli A, et al. Mixed cryoglobulinemia: demographic, clinical, and serological features and survival in 231 patients. Semin Arthritis Rheum 2004; 33: 355-74.

30. Sansonno D, Cornacchiuolo V, Iacobelli A, Di Stefano R, Lospalluti M, Dammacco F. Localization of hepatitis $\mathrm{C}$ virus antigens in liver and skin tissues of chronic hepatitis $\mathrm{C}$ virus infected patients with mixed cryoglobulinemia. Hepatol 1995; 21: 305-12.

31. Sabry A, El-Agroudy A, Sheashaa H, ElHussein, A, Mohamed N, Elbaz M, et al. HCV associated glomerulopathy in Egyptian patients: clinicopathological analysis. Virol 2005; 334: 106. 
32. Cacoub P, Saadoun D, Limal N, Leger J, Maisonobe T. Hepatitis $\mathrm{C}$ virus infection and mixed cryoglobulinaemia vasculitis: a review of neurological complications. AIDS 2005; 19: 12834.

33. Saadoun, D.; Landau, D..; Calabrese, L. and Cacoub, P. (2007): Hepatitis C-associated mixed cryoglobulinaemia: a cross road between autoimmunity and lymphoproliferation. Rheumatol 2007; 46: 1234-42.

34. Gertz MA. Cold agglutinin disease and cryoglobulinemia. Clinical Lymphoma 2005; 5: 290-93.

35. D'Amico G. Renal involvement in hepatitis C infection: cryoglobulinemic glomerulonephritis. Kidney Int 1998; 54: 650-71.

36. Hausfater P, Cacoub P, Assogba U, Lebon P, Piette J. Plasma exchange and interferon-alpha pharmacokinetics in patients with hepatitis $\mathrm{C}$ virus-associated systemic vasculitis. Nephron 2002; 91: 627-30.

37. Boonyapisit K, Katirji B. Severe exacerbation of hepatitis C-associated vasculitic neuropathy following treatment with interferon alpha: a case report and literature review. Muscle Nerve 2002; 25: 909-13.

38. Misiani R, Bellavita P, Baio P, Caldara R, Ferruzzi S, Rossi P, et al. Successful treatment of $\mathrm{HCV}$-associated cryoglobulinaemic glomerulonephritis with a combination of interferon-alpha and ribavirin. Nephrol Dial Transplant 1999; 14: 1558-60.

39. Heathcote E, Shiffman M, Cooksley W, Dusheiko G, Lee S, Balart L, et al. Peginterferon alfa-2a in patients with chronic hepatitis $\mathrm{C}$ and cirrhosis. N Engl J Med 2000; 343: 1673-80.

40. Fried M, Shiffman M, Reddy K, Smith C, Marinos G, Gonçales F, et al. (2002): Peginterferon alfa-2a plus ribavirin for chronic hepatitis C virus infection. $N$ Engl J Med 2002; 347: 975-82.

41. Ballare M, Bobbio F, Poggi S, Bordin G, Bertoncelli M, Catania E, et al. A pilot study on the effectiveness of cyclosporine in type II mixed cryoglobulinemia. Clin Exp Rheumatol 1995; 13: 201-3.

42. De Vita S, Quartuccio L. Treatment of rheumatoid arthritis with rituximab: an update and possible indications. Autoimmun Rev 2006; 5: 443-8.

43. Cheung MC, Haynes AE, Meyer RM, Stevens A, Imrie KR. Rituximab in lymphoma: a systematic review and consensus practice guideline from Cancer Care Ontario. Cancer Treat Rev 2007; 33: 161-76.

44. Sansonno D, De Re V, Lauletta G, Tucci F, Boiocchi M, Dammacco F. Monoclonal antibody treatment of mixed cryoglobulinemia resistant to interferon alpha with an anti-CD20. Blood 2003; 101: 3818-26.
45. Agnello, V. Therapy for cryoglobulinemia secondary to hepatitis $\mathrm{C}$ virus: the need for tailored protocols and multiclinic studies. J Rheumatol 2000; 27(9): 2065-7.

46. Neal J, Gerond V. Hepatitis C virus-related mixed cryoglobulinemia: pathogenesis, clinical manifestations, and new therapies. Gastroenterol \& Hepatol 2007; 3: 697-8.

47. Ramos-Casals M, Trejo O, Garcia-Carrasco M, Font J. Therapeutic management of extrahepatic manifestations in patients with chronic hepatitis C virus infection. Rheumatol 2003; 42: 818-28.

48. Luppi M, Longo G, Ferrari MG, Barozzi P, Marasca R, Morselli M, et al. Clinicopathological characterization of hepatitis $\mathrm{C}$ virusrelated B-cell non-Hodgkin's lymphomas without symptomatic cryoglobulinemia. Ann Oncol 1998; 9: 495-8.

49. Mele A, Pulsioni A, Bianco E, Musto P, Szklo A, Sanpaolo M, et al. Hepatitis C virus and B-cell non-Hodgkin lymphomas: an Italian multicenter case-control study. Blood 2003; 102: 996-9.

50. Duberg A, Nordstrom M, Torner A, Reichard O, Strauss R, Janzon R, et al. Non-Hodgkin's lymphoma and other nonhepatic malignancies in Swedish patients with hepatitis $C$ virus infection. Hepatol 2005; 41: 652-9.

51. Dammacco F, Sansonno D, Piccoli C, Racanelli V, D'Amore FP, Lauletta G. The lymphoid system in hepatitis $\mathrm{C}$ virus infection: autoimmunity, mixed cryoglobulinemia, and overt B-cell malignancy. Semin Liver Dis 2000; 20: 143-57.

52. Zuckerman E, Zuckerman T. Hepatitis C and Bcell lymphoma: the hematohepatologist linkage. Blood Rev 2000; 16: 119-25.

53. Gisbert J, Garcia-Buey L, Pajares J, MorenoOtero R. Prevalence of hepatitis $\mathrm{C}$ virus infection in B-cell non-Hodgkin's lymphoma: systematic review and meta-analysis. Gastroenterol 2003; 125: $1723-32$.

54. Zignego A, Giannelli F, Marocchi M, Mazzocca A, Ferri C, Giannini C, et al. T $(14 ; 18)$ translocation in chronic hepatitis $\mathrm{C}$ virus infection. Hepatol 2000; 31: 474-9.

55. Zignego A, Craxi A. Extrahepatic manifestations of hepatitis $\mathrm{C}$ virus infection. Clin Liver Dis 2008; 12: 611-36.

56. Ferri C, Pileri S, Zignego A. Hepatitis C virus infection and non-Hodgkin's lymphoma. In: Geodert JJ, editor. Infectious causes of cancer. Targets for intervention. Totowa (NJ): The Human Press Inc 2000; 349-68.

57. Trejo O, Ramos-Casals M, Lopez-Guillermo A, García-Carrasco M, Yagüe J, Cervera R, et al. Hematologic malignancies in patients with cryoglobulinemia: association with autoimmune and chronic viral diseases. Semin Arthritis Rheum 2003; 33: 19-28. 
58. Ascoli V, Lo Coco F, Artini M, Levrero M, Martelli M, Negro F. Extranodal lymphomas associated with hepatitis $\mathrm{C}$ virus infection. $\mathrm{Am} J$ Clin Pathol 1998; 109: 600-9.

59. Tursi A, Brandimante G, Chiarelli F, Spagnoli A, Torello M. Detection of HCV RNA in gastric mucosa-associated lymphoid tissue by in situ hybridization: evidence of a new extrahepatic localization of $\mathrm{HCV}$ with increased risk of gastric MALT lymphoma. Am J Gastroenterol 2002; 97: 1802-6.

60. Arcaini L, Paulli M, Boveri E, Vallisa D, Bernuzzi P, Orlandi E, et al. Splenic and nodal marginal zone lymphomas are indolent disorders at high hepatitis $\mathrm{C}$ virus seroprevalence with distinct presenting features but similar morphologic and phenotypic profiles. Cancer 2004; 100: 107-15.

61. Andreone P, Zignego AL, Cursaro C, Gramenzi A, Gherlinzoni F, Fiorino S, et al. Prevalence of monoclonal gammopathies in patients with hepatitis C virus infection. Ann Intern Med 1998; 129: 294-8.

62. Jaffe ES, Harris NL, Stein H, Vardiman JW. Tumours of haematopoietic and lymphoid tissues. World Health Organization classification of tumours. Lyon (France): IARC Press 2001; $75-107$.

63. Soresi M, Carroccio A, Bonfissuto G, Agate V, Magliarisi C, Aragona F, et al. Ultrasound detection of abdominal lymphadenomegaly in subjects with hepatitis $\mathrm{C}$ virus infection and persistently normal transaminases: a predictive index of liver histology severity. J Hepatol 1998; 28: 544-9.

64. Gisbert J, Garcia-Buey L, Pajares J, MorenoOtero R. Systematic review: regression of lymphoproliferative disorders after treatment for hepatitis C infection. Aliment Pharmacol Ther 2005; 21: 653-62.

65. Vallisa D, Bernuzzi P, Arcaini L, Sacchi S, Callea V, Marasca R, et al. Role of anti-hepatitis $\mathrm{C}$ virus (HCV) treatment in HCV-related, lowgrade, non-Hodgkin's lymphoma: a multicenter Italian experience. J Clin Oncol 2005; 23: 46873.

66. Levine A, Shimodaira S, Lai M. Treatment of HCV-related mantle-cell lymphoma with ribavirin and pegylated Interferon alfa. $N$ Engl $J$ Med 2003; 349: 2078-9.

67. Giannelli F, Moscarella S, Giannini C, Caini P, Monti M, Gragnani L, et al. Effect of antiviral treatment in patients with chronic $\mathrm{HCV}$ infection and $\mathrm{t}(14 ; 18)$ translocation. Blood 2003; 102: 1196-201.

68. Saadoun D, Suarez F, Lefrere F, Valensi F, Mariette X, Aouba A, et al. Splenic lymphoma with villous lymphocytes, associated with type II cryoglobulinemia and HCV infection: a new entity? Blood 2005; 105: 74-6.
69. Cheung MC, Haynes AE, Meyer RM, Stevens A, Imrie KR. Rituximab in lymphoma: a systematic review and consensus practice guideline from Cancer Care Ontario. Cancer Treat Rev 2007; 33: 161-76.

70. Dundar Y, Bagust A, Hounsome J, McLeod C, Boland A, Davis H, et al. Rituximab for the firstline treatment of stage III/IV follicular nonHodgkin's lymphoma. Health Technol Assess 2009; 13: 23-8.

71. Aksoy S, Abali H, Kilickap S, Erman M, Kars A. Accelerated hepatitis $\mathrm{C}$ virus replication with rituximab treatment in a non-Hodgkin's lymphoma patient. Clin Lab Haematol 2006; 28: 211-4.

72. Galossi Al, Guarisco R, Bellis L, Puoti C. Extrahepatic manifestations of chronic HCV infection. $J$ Gastrointestin Liver Dis 2007; 16: 65-73.

73. Fargion S, Piperno A, Cappellini M, Sampietro M, Fracanzani AL, Romano R, et al. Hepatitis C virus and porphyria cutanea tarda: evidence of a strong association. Hepatol 1992; 16: 1322-6.

74. Kondo M, Horie Y, Okano J, Kitamura A, Maeda N, Kawasaki H, et al. High prevalence of hepatitis $\mathrm{C}$ virus infection in Japanese patients with porphyria cutanea tarda. Hepatol 1997; 26: 246.

75. O'Reilly F, Darby C, Fogarty J, O'Moore R, Courtney M, O'Connor J, et al. Porphyrin metabolism in hepatitis $\mathrm{C}$ infection. Photodermatol Photoimmunol Photomed 1996; 12: 31-3.

76. Bonkovsky H, Poh-Fitzpatrick M, pimstone N, Obando J, Di Bisceglie A, Tattrie C, et al. Porphyria cutanea tarda, hepatitis C, and HFE gene mutations in North America. Hepatol 1998; 27: 1661-9.

77. Phillips J, Bergonia H, Reilly C, Franklin M, Kushner J. A porphomethene inhibitor of uroporphyrinogen decarboxylase causes porphyria cutanea tarda. Proc Natl Acad Sci USA 2007; 104: 5079-84.

78. Rich, MW. Porphyria cutanea tarda. Don't forget to look at the urine. Postgrad Med 1999; 105: 208-10, 213-4.

79. Maticic M. Hepatitis C virus infection: the dermatological perspective. Acta Dermatoven APA 2003; 12: 19-27.

80. Bonkovsky H, Mehta S. Hepatitis C: a review and update. Journal of the American Academy of Dermatol 2001; 44: 159-79.

81. Matii M, Poljak M, Kramar B, Seme K, Brinovec V, Megli- Volkar J. Detection of hepatitis C virus RNA from gingival crevicular fluid and its relation to virus presence in saliva. $J$ Periodontol 2001; 72:11-16.

82. Ali L, Zein N. Hepatitis C infection: a systemic disease with extrahepatic manifestations. Cleve Clin J Med 2005; 72: 1005-8, 1010-4, 1016. 
83. Divano M, Prodi A, Rebora A. Anti-GOR antibodies in lichen planus. Dermatol 1994; 188: 205-6.

84. Erkek E, Bozdogan O, Olut A. Hepatitis C virus infection prevalence in lichen planus: examination of lesional and normal skin of hepatitis $\mathrm{C}$ virus-infected patients with lichen planus for the presence of hepatitis C virus RNA. Clin Exper Dermatol 2001; 26: 540-4.

85. Areias J, Velho GC, Cerqueira R, Barbêdo C, Amaral B, Sanches M, et al. Lichen planus and chronic hepatitis $\mathrm{C}$ : exacerbation of the lichen under interferon-alpha-2a therapy. Eur $J$ Gastroenterol Hepatol 1996; 8: 825-8.

86. Knobler H, Schihmanter R, Zifroni A, Fenakel $\mathrm{G}$, Schattner A. Increased risk of type 2 diabetes in noncirrhotic patients with chronic hepatitis $\mathrm{C}$ virus infection. Mayo Clin Proc 2000; 75: 355-9.

87. Zein N, Abdulkarim A, Wiesner R, Egan K, Persing D. Prevalence of diabetes mellitus in patients with end-stage liver cirrhosis due to hepatitis C, alcohol, or cholestatic disease. $J$ Hepatol 2000; 32: 209-17.

88. Bigam D, Pennington J, Carpentier A, Wanless I, Hemming A, Croxford R, et al. Hepatitis Crelated cirrhosis: a predictor of diabetes after liver transplantation. Hepatol 2000; 32: 87-90.

89. Mehta S, Brancati F, Sulkowski M, Strathdee S, Szklo M, Thomas D. Prevalence of type 2 diabetes mellitus among persons with hepatitis $\mathrm{C}$ virus infection in the United States. Ann Intern Med 2000; 133: 592-9.

90. Konrad T, Zeuzem S, Vicini P, Toffolo G, Briem $\mathrm{D}$, Lormann $\mathrm{J}$, et al. Evaluation of factors controlling glucose tolerance in patients with $\mathrm{HCV}$ infection before and after 4 months therapy with interferon- $\alpha$. Eur J Clin Invest 2000; 30: 111-21.

91. Knobler H, Schattner T. TNF- $\alpha$, chronic hepatitis $\mathrm{C}$ and diabetes: a novel triad. QJM 2005; 98: 1-6.

92. Laskus T, Radkowski M, Wang L, Vargas H, Rakela J. Search for hepatitis C virus extrahepatic replication sites in patients with acquired immunodeficiency syndrome: Specific detection of negative-strand viral RNA in various tissues. Hepatol 1998; 28: 1398-401.

93. Petta S, Camma C, Marco V, Alessi N, Cabibi D, Caldarella $\mathrm{R}$, et al. Insulin resistance and diabetes increase fibrosis in the liver of patients with genotype $1 \mathrm{HCV}$ infection. $A m \quad J$ Gastroenterol 2008; 103: 1136-44.

94. Chehadeh W, Abdella N, Ben-Nakhi A, Al-Arouj M, Al-Nakib W. Risk factors for the development of diabetes mellitus in chronic hepatitis C virus genotype 4 infection. $J$ Gastroenterol Hepatol 2009; 24: 42-8.

95. Fabris P, Betterle C, Greggio N, Zanchetta R, Bosi $\mathrm{E}$, Biasin $\mathrm{M}$, et al. Insulin-dependent diabetes mellitus during alpha-interferon therapy for chronic viral hepatitis. J Hepatol 1998; 28: 514-7.

96. Huang M,Tsai S, Huang B, Sheen I, Yeh C, Liaw Y. Prevalence and significance of thyroid autoantibodies in patients with chronic hepatitis $\mathrm{C}$ virus infection: a prospective controlled study. Clin Endocrinol 1999; 50: 503-9.

97. Fernandez-Soto L, Gonzales A, Escobar-Jimenez F, Vazquez R, Ocete E, Olea N, et al. Increased risk of autoimmune thyroid disease in hepatitis $\mathrm{C}$ vs. hepatitis B before, during and after discontinuing interferon therapy. Arch Intern Med 1998; 158: 1445-8.

98. Antonelli A, Ferri C, Pampana A, Fallahi P, Nesti C, Pasquini M, et al. Thyroid disorders in chronic hepatitis C. Am J Med 2004; 117: 10-3.

99. Muratori L, Bogdanos D, Muratori P, Lenzi M, Granito A, Ma Y, et al. Susceptibility to thyroid disorders in hepatitis C. Clin Gastroenterol Hepatol 2005; 3: 595-603.

100. Deutsch M, Dourakis S, Manesis E, Gioustozi A, Hess G, Horsch A, et al. Thyroid abnormalities in chronic viral hepatitis and their relationship to interferon alpha therapy. Hepatol 1997; 26: 20610.

101. Prummel M, Laurberg P. Interferon-alpha and autoimmune thyroid disease. Thyroid 2003; 13 : 547-51.

102. Ferri C, La Civita L, Fazzi P, Pasero G, Zignego A. Polymyositis, lung fibrosis, and cranial neuropathy in a patient with hepatitis $\mathrm{C}$ virus infection. Arthritis Rheum 1996; 39: 1074-5.

103. Ferri C, La Civita L, Fazzi P, Solfanelli S, Lombardini F, Begliomini E, et al. Interstitial lung fibrosis and rheumatic disorders in patients with hepatitis $\mathrm{C}$ virus infection. $\mathrm{Br} J$ Rheumatol 1997; 36: 360-5.

104. Weidensaul D, Imam T, Holyst M, King P, McMurray R. Polymyositis, pulmonary fibrosis and hepatitis C. Arthritis Rheum 1995; 38: 437-9.

105. Arase Y, Suzuki F, Suzuki Y, Akuta N, Kobayashi M, Kawamura Y, et al. Hepatitis C virus enhances incidence of idiopathic pulmonary fibrosis. World J Gastroenterol 2008; 14: 5880-6.

106. Yamabe H, Johnson R, Gretch D, Osawa H, Inuma H, Sasaki, T. Membranoproliferative glomerulonephritis associated with hepatitis $\mathrm{C}$ virus infection responsive to interferon-alpha. Am J Kidney Dis 1995; 25: 67-9.

107. Kaupke C, Vaziri N. Renal complications of hepatitis C virus infection. West J Med 1996; 164: 442-3.

108. Johnson M, Fisher D, Fenaughty A, Theno S. Hepatitis $\mathrm{C}$ virus and depression in drug users. Am J Gastroenterol 1998; 93: 785-9.

109. Hilsabeck R, Perry W, Hassanein T. Neuropsychological impairment in patients with chronic hepatitis C. Hepatol 2002; 35: 440-6. 
110. Pariante C, Orru M, Baita A, Farci M, Carpiniello B. Treatment with interferon- $\alpha$ in patient with chronic hepatitis and mood or anxiety disorders. Lancet 1999; 354:131-2.

111. Forton D, Thomas H, Murphy C, Allsop J, Foster G, Main J, et al. Hepatitis $\mathrm{C}$ and cognitive impairment in a cohort of patients with mild liver disease. Hepatol 2002; 35: 433-9.

112. Cozzi A, Zignego AL, Carpendo R, Biagiotti T, Aldinucci A, Monti M, et al. (2006): low serum tryptophan levels, reduced macrophage IDO activity and high frequency of psychopathology in HCV patients. J viral Hepat 2006; 13: 402-8.

113. Porter L. HCV and mental health: Overview of depression. Hepatitis C Support Project (HCSP); Available at http//:www.hcvadvocate.org. Last modified at April 2009. Last cited at 11/10/2009.

114. Franciscus A. HCV - Extrahepatic Manifestations: Peripheral Neuropathy (PN). Hepatitis C Support Project (HCSP); Available at http//: www.hcvadvocate.org. Last modified at February 2009. Last cited at 21/8/2009.

115. Apartis E, Le'ger J, Musset L, Gugenheim M, Cacoub P, Lyon-Caen O, et al. Peripheral neuropathy associated with essential mixed cryoglobulinemia: a role for hepatitis $\mathrm{C}$ virus infection? J Neurol Neurosurg Psychiatry 1996; 60: 661-6.

116. Yamamoto T, Katayama I, Nishioka K. Psoriasis and hepatitis C virus. Acta Derm Venereol 1995; 75: 482-3.

117. Cecchi R, Bartoli L. Psoriasis and hepatitis C treated with anti-TNF alpha therapy (etanercept). Dermatol Online J 2006; 12: 4.

118. Magliocco M, Gottlieb A. Etanercept therapy for patients with psoriatic arthritis and concurrent hepatitis $\mathrm{C}$ virus infection: report of 3 cases. $J$ Am Acad Dermatol 2004; 51: 580-4.

119. Buskila D. (2000): Hepatitis C-associated arthritis. Curr Opin Rheumatol 2000; 12: 295-9.

120. Zuckerman E, Zuckerman T, Sahar D, Streichman S, Attias D, Sabo E, et al. The effect of antiviral therapy on $\mathrm{t}(14 ; 18)$ translocation and immunoglobulin gene rearrangement in patients with chronic hepatitis $\mathrm{C}$ virus infection. Blood 2001; 97: 1555-9.

121. Kessel A, Rosner I, Zuckerman E, Golan T, Toubi E. Use of antikeratin antibodies to distinguish between rheumatoid arthritis and polyarthritis associated with hepatitis C infection. J Rheumatol 2000; 27: 610-2.

122. Sene D, Ghillani-Dalbin P, Limal N, Thibault V, van Boekel T, Piette J-C, et al. Anti-cyclic citrullinated peptide antibodies in hepatitis $\mathrm{C}$ virus associated rheumatological manifestations and Sjögren's syndrome. Ann Rheum Dis 2006; 65: 394-7.

123. Gordon S. Extrahepatic manifestations of hepatitis C. Dig Dis 1996; 14: 157-68.
124. Rivera J, De Diego A, Trinchest M, Garcia A. Fibromyalgia-associated hepatitis $\mathrm{C}$ virus infection, Br J Rheumatol 1997; 36: 981-5.

125. Middleton G, McFarlin J, Lipsky P. The prevalence and clinical impact of fibromyalgia in systemic lupus erythematosus. Arthritis Rheum 1994; 37: 1181-8.

126. Kanazawa K, Yaoita H, Murata K, Tsuda F, Okamoto H. Association of prurigo with hepatitis C virus infection. Dermatol 1995; 131: 825-53.

127. Fisher D, Wright T. Pruritus as a symptom of hepatitis C. J Am Acad Dermatol 1994; 30: 62932.

128. Cordel N, Chosidow O, Frances C. Cutaneous disorders associated with hepatitis $\mathrm{C}$ virus infection. Ann Med Intern (Paris) 2000; 151: 4652.

129. Khanna V, Shieh S, Benjamin J, Somach S, TarifZaim M, Dorner J, et al. Necrolytic acral erythema associated with hepatitis C. Dermatol 2000; 136: 755-7.

130. Wilson S, Lee W, Murakami C, Weng J, Moninger G. Mooren- type hepatitis C virus-associated corneal ulceration. Ophthalmol 1994; 101: 736-45.

131. Matsumori A, Ohashi N, Hasegawa K, Sasayama $\mathrm{S}$, Eto $\mathrm{T}$, Imaizumi $\mathrm{T}$, et al. Hepatitis $\mathrm{C}$ virus infection and heart diseases: A multicenter study in Japan. Jpn Circ J 1998; 62: 389-91.

132. Prati D, Poli F, Farma E, Picone A, Porta E, De Mattei C, et al. Multicenter study on hepatitis C virus infection in patients with dilated cardiomyopathy. North Italy Transplant Program (NITP). J Med Virol 1999; 58: 116-20.

133. Reis F, Viana M, Oliveira M, Sousa T, Parana R. Prevalence of hepatitis $\mathrm{C}$ and $\mathrm{B}$ virus infection in patients with idiopathic dilated cardiomyopathy in Brazil: a pilot study. Braz J Infect Dis 2007; 11: 318-21.

134. Takashi O, Minoru Y, Tetsuya H, Shuhei N, Masahiko K, Shinichiro H, et al. Core protein of hepatitis $\mathrm{C}$ virus induces cardiomyopathy. Circ Res 2005; 96: 148-50.

135. Matsumori A, Matoba Y, Sasayama S. Dilated cardiomyopathy associated with hepatitis $\mathrm{C}$ virus infection. Circ 1995; 92: 2519-25.

136. Liu P, Mason J. Advances in the understanding of myocarditis. Circulation 2001; 104: 1076-82.

137. Ono K, Matsumori A, Shioi T, Furukawa Y, Sasayama S. Cytokine gene expression after myocardial infarction in rat heart: possible implication in left ventricular remodeling. Circ 1998; 98: 149-56.

138. Okabe M, Fukuda K, Arakawa K, Kikuchi M. Chronic variant of myocarditis associated with hepatitis C virus infection. Circ 1997; 96: 22-4.

139. Sanchez M, Bergasa N. Hepatitis C associated cardiomyopathy: potential pathogenic mechanisms and clinical implications. Med Sci Monit 2008; 14: 55-63. 
140. Rajan S, Espina B, Liebman H. Hepatitis C virus related thrombocytopenia: clinical and laboratory characteristics compared with chronic immune thrombocytopenic purpura. Br J Haematol 2005; 129: 818-4.

141. Hamaia S, Li C, Allain J. The dynamics of hepatitis $\mathrm{C}$ virus binding to platelets and 2 mononuclear cell lines. Blood 2001; 98: 2293300.

142. De Almeida A, Campos-de-Magalhaes M, De Melo Marçal O, Brandão-Mello C, Okawa M, Vieira de Oliveira R, et al. Hepatitis C virusassociated thrombocytopenia: a condition prospective, virological study. Ann Hematol 2004; 83: 434-40.

143. Iga D, Tomimatsu M, Endo H, Ohkawa S, Yamada O. Improvement of thrombocytopenia with disappearance of HCV RNA in patients treated by interferon- $\alpha$ therapy: possible etiology of $\mathrm{HCV}$ associated immune thrombocytopenia. Eur J Hematol 2005; 75: 417-23.

144. Hennepin County Medical Center. Management of $\mathrm{HCV}$ and treatment side effects. HCMC Coinfection Clinic. Last modified at April 10, 2005. Last cited at 30/10/2009.

145. McHutchison J, Dusheiko G, Shiffman M, Rodriguez-Torres M, Sigal S, Bourliere M, et al. Eltrombopag for thrombocytopenia in patients with cirrhosis associated with hepatitis C. N Engl $J$ Med 2007; 357: 2227-36.

146. Weitz IC. Treatment of immune thrombocytopenia associated with interferon therapy of hepatitis $\mathrm{C}$ with the anti-CD20 monoclonal antibody, rituximab. Am J Hematol 2005; 78: 138-41. 